\title{
Short communication: Effects of high-pressure processing on the inactivity of Cronobacter sakazakii in whole milk and skim milk samples
}

\author{
Rui Jiao, ${ }^{*} \dagger$ Jina Gao, ${ }^{*}$ Yinxiang Li, ${ }^{*}$ Xiyan Zhang, ${ }^{*}$ Maofeng Zhang, ${ }^{*}$ Yingwang Ye, ${ }^{*}{ }^{1}$ Qingping Wu, $\dagger$ \\ and Hongying Fanł \\ ${ }^{*}$ Center of Detection and Control of Foodborne Risk Factors, School of Food Science and Engineering, Hefei University of Technology, Hefei, \\ 230009, China \\ †State Key Laboratory of Applied Microbiology, South China (the Ministry-Province Joint Development), Provincial Key Laboratory \\ of Microbiology Culture Collection and Application, Guangdong Institute of Microbiology, Guangzhou, 510070, China \\ $\ddagger$ School of Public Health and Tropical Medicine, Southern Medical University, Guangzhou, Guangdong Province, 510515, China
}

\section{ABSTRACT}

Powdered infant formula is considered as the main transmission vehicle for Cronobacter sakazakii infections including meningitis, septicemia, and necrotizing enterocolitis. The effects of high-pressure processing treatment on inactivation of $C$. sakazakii ranging from 100 to $400 \mathrm{MPa}$ for 3.0, 5.0, and $7.0 \mathrm{~min}$ in whole milk and skim milk were studied. Significant differences in inactivation of C. sakazakii were observed in milk samples under different pressures for 3 to $7 \mathrm{~min}$ compared with untreated samples, and C. sakazakii was not detected after $400 \mathrm{MPa}$ for $3 \mathrm{~min}$. The lethality rates of C. sakazakii cells in whole and skim milk with an initial level of $10^{4} \mathrm{cfu} / \mathrm{mL}$ after 100 and $200 \mathrm{MPa}$ treatments were not significantly different, but relatively higher lethality rates were found in whole milk after $300 \mathrm{MPa}$ treatment than in skim milk. Finally, the scanning electron micrographs indicated that cellular envelope and intracellular damage of $C$. sakazakii cells were apparent after 300 and $400 \mathrm{MPa}$ for 5.0 min compared with the untreated cells, and a progressive increase of injured cells with increased pressure treatment was found. It was concluded that C. sakazakii was sensitive to highpressure processing treatment and that high-pressure processing treatment with $400 \mathrm{MPa}$ for 3.0 min can be used to control C. sakazakii contamination in milk samples.

Key words: high-pressure processing, Cronobacter sakazakii, inactivation, whole milk, skim milk

\section{Short Communication}

The genus Cronobacter is a group of foodborne pathogens, including C. sakazakii, C. malonaticus, C.

Received May 7, 2016.

Accepted June 8, 2016.

${ }^{1}$ Corresponding author: yeyw04@mails.gucas.ac.cn turicensis, C. muytjensii, C. condimenti, C. universalis, and $C$. dublinensis, that cause meningitis, septicemia, and necrotizing enterocolitis in neonates (Iversen et al., 2008; Joseph et al., 2012). Epidemiologic surveys indicated that powdered infant formula was the main transmission vehicle for Cronobacter infections (Biering et al., 1989; van Acker et al., 2001; FAO/WHO, 2008). In addition, $\mathrm{Xu}$ et al. (2014) reported that $C$. sakazakii was the most frequent species within the genus of Cronobacter from powdered milk samples. Under various environmental stresses, several studies have shown that Cronobacter species have unusual abilities to survive (Gurtler and Beuchat, 2005; Gurtler et al., 2005; Lin and Beuchat, 2007; Shaker et al., 2008; Ye et al., 2014). Consequently, the control of C. sakazakii is of importance for ensuring microbial safety of milk samples.

High-pressure processing (HPP) is a promising alternative method to conventional thermal pasteurization for improving food safety due to the inactivation of foodborne pathogens (Yang et al., 2012; Yao et al., 2014; Sheen et al., 2015); minimizing the loss of nutrients, such as vitamins, and flavor; and maintaining the quality of food products (Kaletunç et al., 2004; Lee and Kaletunç, 2010). High-pressure processing has been approved to be applied in food processing procedures by the US Food and Drug Administration and the USDA. In recent years, HPP has been used to inactivate the important foodborne pathogens such as Staphylococcus aureus in milk or meat products (Yao et al., 2014), pathogenic Escherichia coli (Sheen et al., 2015), Salmonella (Wang et al., 2013a), Vibrio parahaemolyticus (Wang et al., 2013b), and Listeria monocytogenes (Munoz-Cuevas et al., 2013) in various food samples. However, little research has focused on the inactivation of HPP on C. sakazakii in milk, which is considered the main transmission vehicle.

The current study was to determine the effects of HPP on inactivation of C. sakazakii with different inoculum levels into whole milk and skim milk samples. 
In addition, the morphological changes in HPP-treated C. sakazakii cells was also evaluated using a scanning electron microscope.

The type stain ATCC 29544 was incubated into tryptic soy broth for $16 \mathrm{~h}$ at $37^{\circ} \mathrm{C}$ and different concentrations $\left(3.2 \times 10^{5}\right.$ and $\left.1.7 \times 10^{3} \mathrm{cfu} / \mathrm{mL}\right)$ were obtained using the 10 -fold method. Then, $1.0 \mathrm{~mL}$ of $C$. sakazakii suspension $\left(10^{5}\right.$ and $\left.10^{3} \mathrm{cfu} / \mathrm{mL}\right)$ was incubated with $9 \mathrm{~mL}$ of whole milk and skim milk, respectively. Thus, the whole milk and skim milk samples containing $10^{4}$ or $10^{2} \mathrm{cfu} / \mathrm{mL}$ were prepared. The whole milk and skim milk samples incubated with $C$. sakazakii were treated with HPP using 100, 200, 300, and $400 \mathrm{MPa}$ for $0 \mathrm{~min}$ (control samples), 3.0, 5.0, and $7.0 \mathrm{~min}$. Each experiment was performed in triplicate.

After HPP treatment, the survival of C. sakazakii was counted using the 10-fold dilution method. The lethality rate was determined as the decreasing percentage between colony counts of the control (untreated) and treated milk samples. Each experiment was replicated 3 times.

Under 100 to $400 \mathrm{MPa}$ pressure treatment for 3.0, 5.0 , and $7.0 \mathrm{~min}$, a significant difference $(P<0.05)$ of survival of $C$. sakazakii under the holding times was observed (Table 1). In addition, different inactivation under 200 to $400 \mathrm{MPa}$ treatments was extremely significant $(P<0.01)$ compared with untreated whole milk samples. The inactivation effect of HPP was significantly enhanced by increased pressure intensity $(P$ $<0.05$ ), and cell counts were not detected at $400 \mathrm{MPa}$ for 3.0 min. Similar results of survival of C. sakazakii in skim milk samples after HPP treatment are shown in Table 1. Yao et al. (2014) reported that $S$. aureus in sterile saline and minced meat samples can survive after $450 \mathrm{MPa}$ for $15 \mathrm{~min}$, but no $S$. aureus can be detected after $550 \mathrm{MPa}$ for $3.0 \mathrm{~min}$. Less than $0.5 \mathrm{log}$ $\mathrm{cfu} / \mathrm{mL}$ of $S$. aureus survived after $500 \mathrm{MPa}$ for $5.0 \mathrm{~min}$ in buffered peptone water with an initial inoculum of $10^{4} \mathrm{cfu} / \mathrm{mL}$ (Yuste et al., 2004). Wuytack et al. (2002) found no significant reduction of $S$. aureus after 400 $\mathrm{MPa}$ for $15 \mathrm{~min}$ in PBS buffer. Munoz-Cuevas et al. (2013) reported that reduction of Listeria monocytogenes in nonselective medium was about $3 \log \mathrm{cfu} / \mathrm{mL}$ after $400 \mathrm{MPa}$ for $3.0 \mathrm{~min}$. Gram-negative bacteria might be more sensitive to HPP treatment due to the structure and composition of the outer membrane. For example, the high hydrostatic pressure (300 MPa for $10 \mathrm{~min}$ ) could extensively inactivate Vibrio parahaemolyticus from $10^{9} \mathrm{cfu} / \mathrm{mL}$ to no viable cells (Wang et al., 2013b). After high hydrostatic pressure (350 MPa for $5.0 \mathrm{~min}$ ), the number of viable Salmonella enterica decreased from $10^{9} \mathrm{cfu} / \mathrm{mL}$ to no viable cells (Wang et al., 2013a). Consequently, inactivation of HPP on different foodborne bacteria was species or stain dependent.

In addition, the food matrix also played important roles in the inactivation of bacteria (Alpas et al., 2003). In this study, lethality rates of C. sakazakii in whole milk and skim milk were also analyzed. In Table 2 , the lethality rates of $C$. sakazakii cell in whole and skim milk with an initial level of $10^{4} \mathrm{cfu} / \mathrm{mL}$ after the 100 and $200 \mathrm{MPa}$ treatment were not significantly different $(P>0.05)$. In addition, the total tendency of lethality rates in whole milk was lower than in skim milk after 100 and $200 \mathrm{MPa}$ treatment for 3.0 and $5.0 \mathrm{~min}$, indicating that whole milk provided a certain protective effect for inactivation of C. sakazakii under relatively

Table 1. Survival of Cronobacter sakazakii in milk samples after treatment with high-pressure processing

\begin{tabular}{|c|c|c|c|c|c|}
\hline \multirow[b]{2}{*}{ Sample } & \multirow{2}{*}{$\begin{array}{l}\text { Treatment } \\
\text { time }(\min )\end{array}$} & \multicolumn{4}{|c|}{ Survival of C. sakazakii } \\
\hline & & $100 \mathrm{MPa}$ & $200 \mathrm{MPa}$ & $300 \mathrm{MPa}$ & $400 \mathrm{MPa}$ \\
\hline \multirow[t]{8}{*}{ Whole milk } & 0 & $3.2 \pm 0.30 \times 10^{4 \mathrm{~A}, \mathrm{a}}$ & $3.2 \pm 0.30 \times 10^{4 \mathrm{~A}, \mathrm{a}}$ & $3.2 \pm 0.30 \times 10^{4 \mathrm{~A}, \mathrm{a}}$ & $3.2 \pm 0.30 \times 10^{4 \mathrm{~A}, \mathrm{a}}$ \\
\hline & 3 & $2.5 \pm 0.19 \times 10^{4 \mathrm{~A}, \mathrm{bcd}}$ & $1.7 \pm 0.11 \times 10^{4 \mathrm{BCD}, \mathrm{bc}}$ & $0.8 \pm 0.01 \times 10^{3 \mathrm{BC}, \mathrm{bc}}$ & 0 \\
\hline & 5 & $2.3 \pm 0.20 \times 10^{4 \mathrm{~A}, \mathrm{~cd}}$ & $1.2 \pm 0.05 \times 10^{4 \mathrm{CD}, \mathrm{cd}}$ & $0.3 \pm 0.02 \times 10^{3 \mathrm{C}, \mathrm{c}}$ & 0 \\
\hline & 7 & $2.1 \pm 0.03 \times 10^{4 \mathrm{~A}, \mathrm{~d}}$ & $0.8 \pm 0.04 \times 10^{4 \mathrm{D}, \mathrm{d}}$ & 0 & 0 \\
\hline & 0 & $4.6 \pm 0.30 \times 10^{2 \mathrm{~A}, \mathrm{a}}$ & $4.6 \pm 0.30 \times 10^{2 \mathrm{~A}, \mathrm{a}}$ & $4.6 \pm 0.30 \times 10^{2 \mathrm{~A}, \mathrm{a}}$ & $4.6 \pm 0.30 \times 10^{2 \mathrm{~A}, \mathrm{a}}$ \\
\hline & 3 & $3.9 \pm 0.01 \times 10^{2 \mathrm{ABC}, \mathrm{bc}}$ & $1.9 \pm 0.30 \times 10^{2 \mathrm{BCD}, \mathrm{bcd}}$ & $0.7 \pm 0.30 \times 10^{2 \mathrm{BC}, \mathrm{bc}}$ & 0 \\
\hline & 5 & $3.5 \pm 0.03 \times 10^{2 \mathrm{BC}, \mathrm{cd}}$ & $1.5 \pm 0.30 \times 10^{2 \mathrm{CD}, \mathrm{cd}}$ & $0.2 \pm 0.10 \times 10^{2 \mathrm{C}, \mathrm{c}}$ & 0 \\
\hline & 7 & $3.3 \pm 0.04 \times 10^{2 \mathrm{C}, \mathrm{d}}$ & $1.2 \pm 0.25 \times 10^{2 \mathrm{D}, \mathrm{d}}$ & 0 & 0 \\
\hline \multirow[t]{8}{*}{ Skim milk } & 0 & $3.2 \pm 0.15 \times 10^{4 \mathrm{~A}, \mathrm{a}}$ & $3.2 \pm 0.15 \times 10^{4 \mathrm{~A}, \mathrm{a}}$ & $3.2 \pm 0.15 \times 10^{4 \mathrm{~A}, \mathrm{a}}$ & $3.2 \pm 0.15 \times 10^{4 \mathrm{~A}, \mathrm{a}}$ \\
\hline & 3 & $2.2 \pm 0.14 \times 10^{4 \mathrm{BCD}, \mathrm{bcd}}$ & $1.5 \pm 0.07 \times 10^{4 \mathrm{BC}, \mathrm{b}}$ & $6.9 \pm 0.06 \times 10^{3 \mathrm{~B}, \mathrm{~b}}$ & 0 \\
\hline & 5 & $2.1 \pm 0.06 \times 10^{4 \mathrm{CD}, \mathrm{cd}}$ & $1.1 \pm 0.08 \times 10^{4 \mathrm{CD}, \mathrm{cd}}$ & $4.2 \pm 0.02 \times 10^{3 \mathrm{C}, \mathrm{c}}$ & 0 \\
\hline & 7 & $1.9 \pm 0.08 \times 10^{4 \mathrm{D}, \mathrm{d}}$ & $9.2 \pm 0.06 \times 10^{3 \mathrm{D}, \mathrm{d}}$ & $1.2 \pm 0.01 \times 10^{3 \mathrm{D}, \mathrm{d}}$ & 0 \\
\hline & 0 & $5.3 \pm 0.45 \times 10^{2 \mathrm{~A}, \mathrm{a}}$ & $5.3 \pm 0.45 \times 10^{2 \mathrm{~A}, \mathrm{a}}$ & $5.3 \pm 0.45 \times 10^{2 \mathrm{~A}, \mathrm{a}}$ & $5.3 \pm 0.45 \times 10^{2 \mathrm{~A}, \mathrm{a}}$ \\
\hline & 3 & $3.3 \pm 0.25 \times 10^{2 \mathrm{ABC}, \mathrm{bcd}}$ & $1.6 \pm 0.25 \times 10^{2 \mathrm{BCD}, \mathrm{bcd}}$ & $0.8 \pm 0.30 \times 10^{2 \mathrm{BC}, \mathrm{bc}}$ & 0 \\
\hline & 5 & $2.9 \pm 0.40 \times 10^{2 \mathrm{BC}, \mathrm{cd}}$ & $1.1 \pm 0.20 \times 10^{2 \mathrm{CD}, \mathrm{cd}}$ & $0.3 \pm 0.10 \times 10^{2 \mathrm{C}, \mathrm{c}}$ & 0 \\
\hline & 7 & $2.6 \pm 0.04 \times 10^{2 \mathrm{C}, \mathrm{d}}$ & $0.6 \pm 0.15 \times 10^{2 \mathrm{D}, \mathrm{d}}$ & 0 & 0 \\
\hline
\end{tabular}

\footnotetext{
${ }^{\mathrm{a}-\mathrm{d}}$ Within the same column, different superscripts indicate significant differences $(P<0.05)$.

${ }^{\mathrm{A}-\mathrm{D}}$ Within the same column, different superscripts indicate significant differences $(P<0.01)$.
} 
lower pressure. Interestingly, significant differences of lethality rates $(P<0.05)$ were observed in whole milk and skim milk after $300 \mathrm{MPa}$ for 3.0, 5.0, and $7.0 \mathrm{~min}$, and higher lethality rates were found in whole milk than in skim milk. These contradictory findings might be related to the interaction between structure or compositions of outer membrane and fat after HPP, but a detailed mechanism remains to be revealed. Previous studies have indicated that the food matrix has a protective effect on the microorganism against high pressure (Panagou et al., 2007; Yao et al., 2014). A comparison between the survival curves in phosphate buffer and gilt-head seabream showed a clear protective effect of the food matrix on the resistance of Pediococcus damnosus, especially at 500 and $550 \mathrm{MPa}$ (Panagou et al., 2007). After high hydrostatic pressure of 350 and $450 \mathrm{MPa}$ for 3.0, 6.0, 9.0,12, and $15 \mathrm{~min}$, the inactivation of Staphylococcus aureus in sterile saline was higher than in minced meat (Yao et al., 2014). However, no significant differences in inactivation of $E$. coli were observed in cooked ham homogenized with water (3:1) and in phosphate buffer after $500 \mathrm{MPa}$ for $10 \mathrm{~min}$ (Garriga et al., 2002).

Furthermore, C. sakazakii cells were prepared from pressure-treated and untreated cell suspensions via centrifugation at $5,000 \times g$ for $10 \mathrm{~min}$ at room temperature after washing the pellet twice in $0.1 \mathrm{M}$ phosphate buffer ( $\mathrm{pH}$ 7.4). The subsequent steps were described by Wang et al. (2013a). Finally, the morphological changes of C. sakazakii after HPP were analyzed by performing scanning electron microscopy (Hitachi S4700, Hitachi, Tokyo, Japan) at $15 \mathrm{kV}$ voltage, and photomicrographs were obtained.

From Figure 1, scanning electron microscopy indicated that morphological changes of cell structure such as cytomorphosis and cellular crimple were observed after 300 and $400 \mathrm{MPa}$ for $5.0 \mathrm{~min}$, whereas untreated cells exhibited intact cell structure and clear cell wall of C. sakazakii. In addition, a progressive increase of injured cells occurred with increased pressure treatment, which was consistent with the survival of $C$. sakazakii under 300 and $400 \mathrm{MPa}$. After $300 \mathrm{MPa}$ treatment, the structure of some cells was intact, whereas C. sakazakii cells were completely injured under $400 \mathrm{MPa}$. In $V$. parahaemolyticus, some cell disruptions were caused by $300 \mathrm{MPa}$ treatment. Similar results were observed in $E$. coli and $S$. aureus by transmission electron microscopy as described by Yang et al. (2012). In addition, some bud scars were caused and the membrane integrity of cells was lost after HPP treatment in this study, suggesting that the cellular wall and outer membrane might be the main target of HPP. Hayakawa et al. (1994) suggested that protein denaturation might be the main mechanism for inactivation by HPP treatment. Moreover, metabolic activity and membrane potential of foodborne pathogens decreases after HPP treatment (Ritz et al., 2001). We inferred that inactivation of $C$. sakazakii after HPP treatment was associated with cell disruption, and simultaneously the release of cytoplasmic content caused the loss of viability of cells and denaturation of functional components of cells such as enzymes and structural proteins.

\section{ACKNOWLEDGMENTS}

We gratefully acknowledge the financial support of the Anhui Provincial Grand Project Special of Science and Technology (15czz03109; China) and the Science and Technology Planning Project of Guangdong Province, China (2013B021500012).

Table 2. The comparison of lethality rate (\%) between whole and skim milk after high-pressure processing (HPP) treatment

\begin{tabular}{|c|c|c|c|c|c|}
\hline HPP & $\begin{array}{l}\text { Treated } \\
\text { time (min) }\end{array}$ & \multicolumn{2}{|c|}{$10^{4} \mathrm{cfu} / \mathrm{mL}$} & \multicolumn{2}{|c|}{$10^{2} \mathrm{cfu} / \mathrm{mL}$} \\
\hline \multirow[t]{3}{*}{$100 \mathrm{MPa}$} & 3 & $21.88 \pm 5.93^{\mathrm{A}, \mathrm{a}}$ & $34.46 \pm 4.31^{\mathrm{A}, \mathrm{a}}$ & $15.22 \pm 0.22^{\mathrm{A}, \mathrm{a}}$ & $37.74 \pm 4.72^{\mathrm{A}, \mathrm{b}}$ \\
\hline & 5 & $28.13 \pm 6.25^{\mathrm{A}, \mathrm{a}}$ & $36.62 \pm 1.85^{\mathrm{A}, \mathrm{a}}$ & $23.91 \pm 0.65^{\mathrm{A}, \mathrm{a}}$ & $45.28 \pm 7.55^{\mathrm{A}, \mathrm{a}}$ \\
\hline & 7 & $34.34 \pm 0.94^{\mathrm{A}, \mathrm{a}}$ & $40.31 \pm 2.46^{\mathrm{A}, \mathrm{a}}$ & $28.26 \pm 0.87^{\mathrm{A}, \mathrm{a}}$ & $50.94 \pm 0.75^{\mathrm{B}, \mathrm{b}}$ \\
\hline \multirow[t]{2}{*}{$200 \mathrm{MPa}$} & 3 & $46.88 \pm 3.44^{\mathrm{A}, \mathrm{a}}$ & $55.08 \pm 2.15^{\mathrm{A}, \mathrm{a}}$ & $58.70 \pm 6.52^{\mathrm{A}, \mathrm{a}}$ & $69.81 \pm 4.72^{\mathrm{A}, \mathrm{a}}$ \\
\hline & 5 & $62.50 \pm 1.56^{\mathrm{A}, \mathrm{a}}$ & $66.15 \pm 2.46^{\mathrm{A}, \mathrm{a}}$ & $67.39 \pm 6.52^{\mathrm{A}, \mathrm{a}}$ & $79.25 \pm 3.77^{\mathrm{A}, \mathrm{a}}$ \\
\hline \multirow{2}{*}{$300 \mathrm{MPa}$} & 5 & $99.06 \pm 0.63^{\mathrm{A}, \mathrm{a}}$ & $87.08 \pm 0.62^{\mathrm{B}, \mathrm{b}}$ & $95.65 \pm 2.17^{\mathrm{A}, \mathrm{a}}$ & $94.34 \pm 1.89^{\mathrm{A}, \mathrm{a}}$ \\
\hline & 7 & 100 & $96.31 \pm 0.31^{\mathrm{A}, \mathrm{a}}$ & 100 & 100 \\
\hline \multirow[t]{3}{*}{$400 \mathrm{MPa}$} & 3 & 100 & 100 & 100 & 100 \\
\hline & 5 & 100 & 100 & 100 & 100 \\
\hline & 7 & 100 & 100 & 100 & 100 \\
\hline
\end{tabular}

$\overline{\mathrm{a}, \mathrm{b}}$ Different superscripts in the same row indicate significant differences $(P<0.05)$.

${ }^{\mathrm{A}, \mathrm{B}}$ Different superscripts indicate significant differences $(P<0.01)$. 

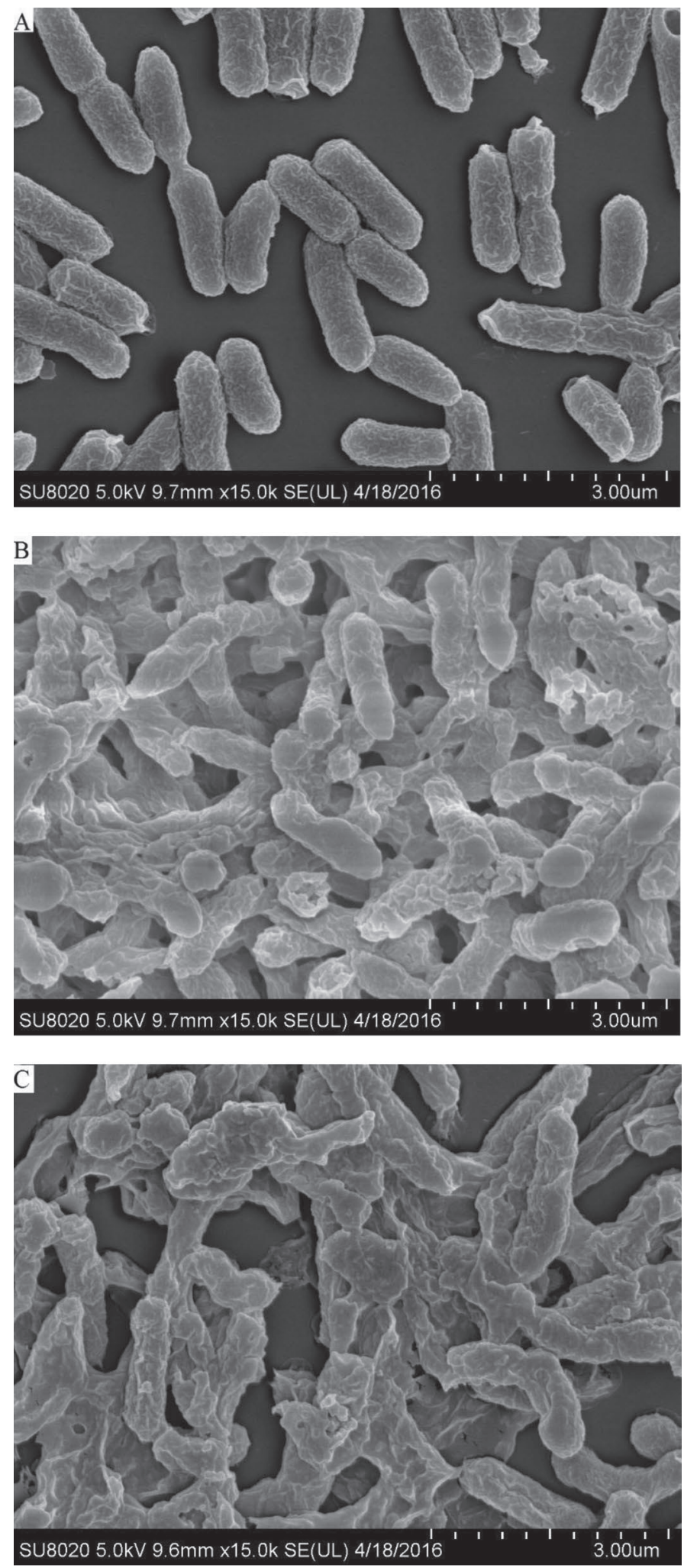

Figure 1. Scanning electron micrographs of Cronobacter sakazaki cells. (A) Untreated cells, (B) cells treated at $300 \mathrm{MPa}$ for $5 \mathrm{~min}$, and (C) cells treated at $400 \mathrm{MPa}$ for $5 \mathrm{~min}$.

\section{REFERENCES}

Alpas, H., L. Alma, and F. Bozoglu. 2003. Inactivation of Alicyclobacillus acidoterrestris vegetative cells in model system, apple, orange and tomato juices by high hydrostatic pressure. World J. Microbiol. Biotechnol. 19:619-623.

Biering, G., S. Karlsson, N. V. C. Clark, K. E. Jonsdottir, P. Ludvigsson, and O. Steingrimsson. 1989. Three cases of neonatal meningitis caused by Enterobacter sakazakii in powdered milk. J. Clin. Microbiol. 27:2054-2056.

FAO/WHO (Food and Agriculture Organization of the United Nations/World Health Organization). 2008. Enterobacter sakazakii (Cronobacter spp.) in powdered follow-up formulae. Microbiological Risk Assessment Series No. 15. Food and Agriculture Organization of the United Nations/World Health Organization, Rome, Italy.

Garriga, M., M. T. Aymerich, S. Costa, J. M. Monfort, and M. Hugas. 2002. Bactericidal synergism through bacteriocins and high pressure in a meat model system during storage. Food Microbiol. 19:509-518.

Gurtler, J. B., and L. R. Beuchat. 2005. Performance of media for recovering stressed cells of Enterobacter sakazakii as determined using spiral plating and ecometric techniques. Appl. Environ. Microbiol. 71:7661-7669.

Gurtler, J. B., J. L. Kornacki, and L. R. Beuchat. 2005. Enterobacter sakazakii: A coliform of increased concern to infant health. Int. J. Food Microbiol. 104:1-34

Hayakawa, I., T. Kanno, M. Tomita, and Y. Fujio. 1994. Application of high pressure for spore inactivation and protein denaturation. J. Food Sci. 59:159-163.

Iversen, C., N. Mullane, B. McCardell, B. D. Tall, A. Lehner, S. Fanning, R. Stephan, and H. Joosten. 2008. Cronobacter gen. nov., a new genus to accommodate the biogroups of Enterobacter sakazakii, and proposal of Cronobacter sakazakii gen. nov., comb. nov., Cronobacter malonaticus sp. nov., Cronobacter turicensis sp. nov., Cronobacter muytjensii sp. nov., Cronobacter dublinensis sp. nov., Cronobacter genomo-species 1, and of three subspecies, Cronobacter dublinensis ssp. dublinensis ssp. nov., Cronobacter dublinensis ssp. lausannensis ssp. nov. and Cronobacter dublinensis ssp. lactaridi ssp. nov. Int. J. Syst. Evol. Microbiol. 58:1442-1447.

Joseph, S., E. Cetinkaya, H. Drahovska, A. Levican, M. J. Figueras, and S. J. Forsythe. 2012. Cronobacter condimenti sp. nov., isolated from spiced meat, and Cronobacter universalis sp. nov., a species designation for Cronobacter sp. genomospecies 1, recovered from a leg infection, water and food ingredients. Int. J. Syst. Evol. Microbiol. 62:1277-1283.

Kaletunç, G., J. Lee, H. Alpas, and F. Bozoglu. 2004. Evaluation of structural changes induced by high hydrostatic pressure in Leuconostoc mesenteroides. Appl. Environ. Microbiol. 70:1116-1122.

Lee, J., and G. Kaletunç. 2010. Inactivation of Salmonella Enteritidis strains by combination of high hydrostatic pressure and nisin. Int. J. Food Microbiol. 140:49-56.

Lin, L.-C., and L. R. Beuchat. 2007. Survival of Enterobacter sakazakii in infant cereal as affected by composition, water activity, and temperature. Food Microbiol. 24:767-777.

Munoz-Cuevas, M., L. Guevara, A. Aznar, A. Martinez, P. M. Periago, and P. S. Fernandez. 2013. Characterization of the resistance and the growth variability of Listeria monocytogenes after high hydrostatic pressure treatments. Food Contr. 29:409-415.

Panagou, E. Z., C. C. Tassou, C. Manitsa, and C. Mallidis. 2007. Modelling the effect of high pressure on the inactivation kinetics of a pressure-resistant strain of Pediococcus damnosus in phosphate buffer and gilt-head seabream (Sparus aurata). J. Appl. Microbiol. 102:1499-1507.

Ritz, M., J. L. Tholozan, M. Federighi, and M. F. Pilet. 2001. Morphological and physiological characterization of Listeria monocytogenes subjected to high hydrostatic pressure. Appl. Environ. Microbiol. 67:2240-2247.

Shaker, R. R., T. M. Osaili, A. S. Al-Hasan, M. M. Ayyash, and S. J. Forsythe. 2008. Effect of desiccation, starvation, heat, and cold 
stresses on the thermal resistance of Enterobacter sakazakii in rehydrated infant milk formula. J. Food Sci. 73:M354-M359.

Sheen, S., J. Cassidy, B. Scullen, and C. Sommers. 2015. Inactivation of a diverse set of shiga toxin-producing Escherichia coli in ground beef by high pressure processing. Food Microbiol. 52:84-87.

van Acker, J., F. De Smet, G. Muyldermans, A. Bougates, A. Naessens, and S. Lauwers. 2001. Outbreaks of necrotizing enterocolitis associated with Enterobacter sakazakii in powdered milk formulas. J. Clin. Microbiol. 39:293-297.

Wang, C.-Y., C.-P. Hsu, H.-W. Huang, and B. B. Yang. 2013a. The relationship between inactivation and morphological damage of Salmonella enterica treated by high hydrostatic pressure. Food Res. Int. 54:1482-1487.

Wang, C.-Y., H.-W. Huang, C.-P. Hsu, Y.-T. Shyu, and B. B. Yang. 2013b. Inactivation and morphological damage of Vibrio parahaemolyticus treated with high hydrostatic pressure. Food Contr. 32:348-353.

Wuytack, E. Y., A. M. Diels, and C. W. Michiels. 2002. Bacterial inactivation by high-pressure homogenisation and high hydrostatic pressure. Int. J. Food Microbiol. 77:205-212.
Xu, X., Q. P. Wu, J. M. Zhang, Y. W. Ye, X. J. Yang, and X. H. Dong. 2014. Occurrence and characterization of Cronobacter spp. in powdered formula from Chinese retail markets. Foodborne Pathog. Dis. 11:307-312

Yang, B. W., Y. Shi, X. D. Xia, M. L. Xi, X. Wang, B. Y. Ji, and J. H. Meng. 2012. Inactivation of foodborne pathogens in raw milk using high hydrostatic pressure. Food Contr. 28:273-278.

Yao, J., B. Zhou, R. Wang, T. Wang, X. Hu, X. Liao, and Y. Zhang. 2014. Inactivation of Staphylococcus aureus by high hydrostatic pressure in saline solution and meat slurry with different initial inoculum levels. Food Bioprod. Process. 94:592-600.

Ye, Y., H. Li, Q. P. Wu, M. S. Chen, Y. D. Lu, and C. M. Yan. 2014. Isolation and phenotypic characterization of Cronobacter from dried edible macrofungi samples. J. Food Sci. 79:M1382-M1386.

Yuste, J., M. Capellas, D. Y. Fung, and M. Mor-Mur. 2004. Inactivation and sublethal injury of foodborne pathogens by high pressure processing: Evaluation with conventional media and thin agar layer method. Food Res. Int. 37:861-866. 